Check for updates

Cite this: RSC Adv., 2018, 8, 472

Received 22nd September 2017

Accepted 12th December 2017

DOI: 10.1039/c7ra10509f

rsc.li/rsc-advances

\title{
Boosting efficiency and stability using zirconia nanosphere-held carbon for proton exchange membrane fuel cells
}

\author{
P. Dhanasekaran, ${ }^{\text {a Sharon R. Williams, }}{ }^{\text {b }}$ D. Kalpana*a and Santoshkumar D. Bhat (D) *a \\ The synthesis of a zirconia-held carbon supported Pt electrocatalyst increases the fuel cell performance in \\ polymer electrolyte fuel cells. The pure tetragonal phase of the zirconia-carbon composite is synthesized \\ using a low temperature method. The optimum composition of zirconia-carbon exhibits a maximum peak \\ power density of $1.12 \mathrm{~W} \mathrm{~cm}$-2 with a metal (Pt) loading of $150 \mu \mathrm{g} \mathrm{cm}^{-2}$. This also improves long time \\ durability and retains $70 \%$ of its initial activity even after 6000 potential cycles between 1 to $1.6 \mathrm{~V}$ vs. \\ a dynamic hydrogen electrode.
}

\section{Introduction}

The oxygen reduction reaction (ORR) process is critical in polymer electrolyte fuel cells (PEFCs) and to better it, catalyst design with efficiency and long term durability is a vital requirement. Even though the theoretical efficiency of PEFCs is as high as $80 \%$ at $298 \mathrm{~K}$, the practical efficiencies have been in the range of $50-60 \% .^{1-3}$ This is mainly due to the stringent operating conditions of the cell, activation, ohmic and mass transport losses involved in it. In the current scenario, desirable high efficiency and stability of the PEFCs are met by a metal/ metal oxide-carbon based electrocatalyst. According to the previous reports, Pt on carbon shows higher fuel cell performance but lower long-term durability. This is mainly due to the carbon corrosion followed by Pt agglomeration and dissolution. $^{3-5}$ To overcome the same, metal-metal oxide/carbon or metal/metal oxide-carbon composite are explored which retains Pt metal particles and reduces the carbon corrosion resulting in enhanced power output and long term durability in PEFC. ${ }^{6-8}$

In this aspect, zirconia is considered as a material to have excellent mechanical properties, outstanding thermal stability, better corrosion resistance, good chemical stability, proton conductivity and has been widely used in many applications. ${ }^{9,10}$ According to Liu et al., their $\mathrm{Pt}_{4} \mathrm{ZrO}_{2} / \mathrm{C}$ electrocatalyst improved high temperature fuel cell performance and has a higher corrosion resistance than Pt/C. ${ }^{11,12}$ Bai et al., reported that the molar ratio of $\mathrm{Pt}$ and $\mathrm{ZrO}_{2} 1: 4\left(\mathrm{Pt}-\mathrm{ZrO}_{2} /\right.$ carbon) electrocatalyst enhanced the ethanol electro-oxidation reaction than that of $\mathrm{Pt} /$ C. ${ }^{13}$ Similarly, Cheng et al., explored that Pt encapsulated in a zirconia nanocage by area selective atomic layer deposition,

${ }^{a}$ CSIR-Central Electrochemical Research Institute (CECRI), CSIR-Madras Complex, Chennai 600 113, Tamil Nadu, India. E-mail: sdbhatcecri@gmail.com; drkalpanaa@gmail.com; Fax: +91-44-22542456; Tel: +91-44-22544564

${ }^{b}$ Department of Nuclear Physics, University of Madras, Chennai, Tamil Nadu, India indicated very high stability and activity towards ORR. $\mathrm{Pt}-\mathrm{ZrO}_{2} /$ carbon shows nine times more stability than $\mathrm{Pt} / \mathrm{C}$ and this improvement of ORR activity was mainly due to the synergetic effect of $\mathrm{Pt}$ and $\mathrm{ZrO}_{2}{ }^{14}$

In the present studies, we report optimum levels of carbon held in tetragonal $\mathrm{ZrO}_{2}$-phase $(\mathrm{Zr}-\mathrm{C})$ nanospheres supported $\mathrm{Pt}$ can greatly improve the fuel cell performance and platinum stability. To the best of our knowledge, in-depth study of Pt on lower amount of carbon embraced with $\mathrm{ZrO}_{2}$ electrocatalyst for cell mode system and long-term durability has not been reported in the literature. In this study, we have described the low temperature method for the synthesis of high-purity $\mathrm{ZrO}_{2}$ nanoparticles having tetragonal phase followed by compositing different ratios of carbon to it. Finally, Pt is deposited on various ratios of carbon with $\mathrm{ZrO}_{2}$. The structural studies, morphologies, oxidation states and elemental compositions of synthesized electrocatslysts were investigated by various characterizations.

\section{Experimental section}

\section{Carbon held $\mathrm{ZrO}_{2}$ nanospheres by low temperature method}

In brief, $3 \mathrm{ml}$ of zirconium isopropoxide was added drop-wise in to $60 \mathrm{ml}$ of $1: 1$ ratio of ethanol : water mixture followed by stirring for $1 \mathrm{~h}$ at below $5{ }^{\circ} \mathrm{C} .100 \mathrm{mg}$ of Vulcan carbon was dispersed ultrasonically in $5 \mathrm{ml}$ of water and added to the mixture and stirred for $24 \mathrm{~h}$ in an ice bath. The precipitate was washed with Millipore water and dried at $100{ }^{\circ} \mathrm{C}$ for $12 \mathrm{~h}$. Then, the sample was calcined at $500{ }^{\circ} \mathrm{C}$ for $2 \mathrm{~h}$ under nitrogen atmosphere in order to obtain carbon- $\mathrm{ZrO}_{2}$ composites and was marked as Zr-C 1. Similarly, the carbon weight was varied from 0, 200, 300 and $600 \mathrm{mg}$ while keeping the amount of zirconium isopropoxide as a constant and the samples were marked as $\mathrm{ZrO}_{2}, \mathrm{Zr}-\mathrm{C} 2, \mathrm{Zr}-\mathrm{C} 3$ and $\mathrm{Zr}-\mathrm{C} 4$, respectively. 
40 wt\% Pt deposited on carbon held zirconia by polyol method

In brief, $120 \mathrm{mg}$ of $\mathrm{Zr}-\mathrm{C} 1$ was dispersed in $1: 4$ ratio of water : ethylene glycol and stirred for $12 \mathrm{~h}$. The required amount of $\mathrm{H}_{2} \mathrm{PtCl}_{6} \cdot 6 \mathrm{H}_{2} \mathrm{O}$ was dissolved in $1: 3$ ratio of water : ethylene glycol and added dropwise to the above mixture and stirred for $12 \mathrm{~h}$. The $\mathrm{pH}$ was adjusted to 13 by adding $\mathrm{NaOH}$ and the temperature was maintained at $150{ }^{\circ} \mathrm{C}$ for $6 \mathrm{~h}$. The obtained sample was filtered and repeatedly washed with Millipore water and dried at $100{ }^{\circ} \mathrm{C}$ for $12 \mathrm{~h}$. Pt deposited on $\mathrm{Zr}-\mathrm{C} 1$ is represented as $\mathrm{Pt} / \mathrm{Zr}-\mathrm{C} 1$. Similarly, $\mathrm{Pt}$ was deposited by above method on $\mathrm{ZrO}_{2}, \mathrm{Zr}-\mathrm{C} 2, \mathrm{Zr}-\mathrm{C} 3$ and $\mathrm{Zr}-\mathrm{C} 4$ was marked as $\mathrm{Pt} /$ $\mathrm{ZrO}_{2}, \mathrm{Pt} / \mathrm{Zr}-\mathrm{C} 2, \mathrm{Pt} / \mathrm{Zr}-\mathrm{C} 3$ and $\mathrm{Pt} / \mathrm{Zr}-\mathrm{C} 4$ respectively.

\section{Materials and electrochemical characterization}

$\mathrm{X}$-ray diffraction (XRD) patterns were recorded between 10 and $80^{\circ}$ using BRUKER-binary $\mathrm{V} 3$. High resolution transmission electron microscopy (HR-TEM) images were taken on Technai20 G2 and STEM images were recorded using HAADF detector. Field emission scanning electron spectroscopy (FESEM) images were examined from JEOL-7001. X-ray photoelectron spectroscopy (XPS) was measured on Omicron nanotechnology instrument. $\mathrm{CO}_{2}$ emission was observed using $\mathrm{CO}_{2}$ sensor (Vaisala $\mathrm{CO}_{2}$ sensor). The elemental compositions were calculated by ICP-OES (PERKIN ELMER OPTIMA 5300 DV). The percentage of carbon was studied by CHNS analyser using Elementar Vario EL III.

\section{Electrochemical characterization}

The electrochemical studies were accompanied using three electrode electrochemical cell arrangements. A saturated calomel electrode (SCE) and Pt mesh were used as reference and counter electrode, respectively. $2 \mathrm{mg}$ of synthesized electrocatalyst was ultrasonically dispersied with $1.5 \mathrm{ml}$ of water and $5 \mathrm{wt} \%$ of Nafion ionomer solution to obtain the ink. The required amount of ink was uniformly spread on the glassy carbon (GC) electrode. The Pt metal loading on the surface of polished GC disk is maintained about $40 \mu \mathrm{g}_{\mathrm{Pt}} \mathrm{cm}^{-2}$. Cyclic voltammetry $(\mathrm{CV})$ measurements were carried out between 0 to $1 \mathrm{~V}$ with respect to reversible hydrogen electrode (RHE) at a sweep rate of $20 \mathrm{mV} \mathrm{s}^{-1}$ in de-aerated $0.1 \mathrm{M} \mathrm{HClO}_{4}$ electrolyte. Linear sweep voltammogram (LSV) experiments were carried out using rotating disk electrode at a scan rate of $10 \mathrm{mV} \mathrm{s}^{-1}$. The experiments were conducted on Autolab PGSTAT-30 at room temperature at $25{ }^{\circ} \mathrm{C}$. The stability test was carried out by potential between 0.6 and $1.2 \mathrm{~V} v s$. RHE with scan rate of $40 \mathrm{mV} \mathrm{s}^{-1}$.

\section{The membrane electrode assembly (MEA) fabrication and performance evaluation}

In brief, the required amount of synthesized electrocatalyst dispersed in water $(200 \mu \mathrm{l})$ and Nafion $(7 \mathrm{wt} \%$ for anode and $30 \mathrm{wt} \%$ for cathode) was added followed by IPA and sonicated for $45 \mathrm{~min}$. The catalysts were coated on to the commercial carbon paper (DC-35 with GDL thickness of $20 \mu \mathrm{m}$ ) to form the catalyst layers (Pt/C for anode) and (various electrocatalysts for cathode) with a Pt loading of $0.15 \pm 0.01 \mathrm{mg} \mathrm{cm}^{-2}$. MEA was prepared by hot-pressing the Nafion 211 membrane between electrodes, bearing synthesized electrocatalyst $(\mathrm{Pt} / \mathrm{Zr}-\mathrm{C})$ as cathode and commercial $\mathrm{Pt} / \mathrm{C}$ as an anode at $60 \mathrm{~kg} \mathrm{~cm}{ }^{-2}$ and $130{ }^{\circ} \mathrm{C}$ for $2 \mathrm{~min}$. MEAs were assessed for electrochemical performance with $25 \mathrm{~cm}^{2}$ fuel cell setup procured from M/s Fuel Cell Technologies Inc., USA. The steady-state polarization were recorded at $65{ }^{\circ} \mathrm{C}$ under $\mathrm{H}_{2}: \mathrm{O}_{2}$ condition under $100 \%$ relative humidity $(\mathrm{RH})$ at both side and test was carried out FCT $150 \mathrm{~S}$ procured from Bio-Logic science instrument, France. Accelerated stress test (AST) was carried out in the potential range between 1 and $1.6 \mathrm{~V} v$ s. dynamic hydrogen electrode (DHE) at scan rate of $500 \mathrm{mV} \mathrm{s}^{-1}$. The cell temperature was maintained at $75{ }^{\circ} \mathrm{C}$ with fully humidified condition for both anode and cathode, respectively.

\section{Results and discussion}

The X-ray diffraction patterns of $\mathrm{ZrO}_{2}$ and $\mathrm{Zr}-\mathrm{C}$ show sharp " $\mathrm{Z}$ " peaks which are reflections with tetragonal $\mathrm{ZrO}_{2}$ framework lattice plane, in good agreement with JCPDS (88-1007) are shown in Fig. 1. Similarly, "C" peak at $24.8^{\circ}$ is attributed to (002) diffraction plane, confirms that Vulcan carbon has an intermediate structure between amorphous and graphitic nature represented as turbostratic structure. ${ }^{15}$ In the XRD patterns of $\mathrm{Pt}$ deposited on $\mathrm{C}, \mathrm{ZrO}_{2}$ and $\mathrm{Zr}-\mathrm{C}$, the peaks at 39.9, 46.4 and $67.8^{\circ}$ correspond to (111), (200) and (220) planes respectively and this confirms that Pt is in the metallic state with face-centered cubic structure (JCPDS \# 87-0647) as shown in Fig. 1. The average particle size of Pt for Pt deposited $\mathrm{ZrO}_{2}, \mathrm{Zr}-\mathrm{C} 1, \mathrm{Zr}-\mathrm{C} 2, \mathrm{Zr}-\mathrm{C} 3$, $\mathrm{Zr}-\mathrm{C} 4$ and $\mathrm{C}$ are observed as 5.8, 5.2, 5.0, 4.7, 4.2 and $3.5 \pm$

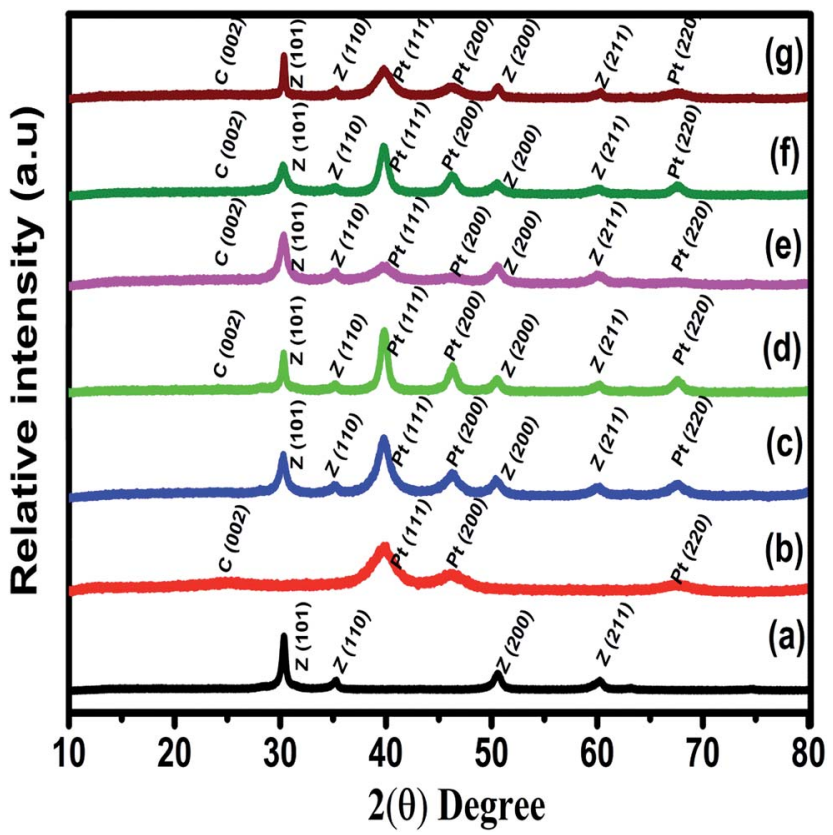

Fig. 1 Powder XRD pattern of (a) $\mathrm{ZrO}_{2}$, (b) $\mathrm{Pt} / \mathrm{C}$, (c) $\mathrm{Pt} / \mathrm{ZrO}_{2}$, (d) $\mathrm{Pt} / \mathrm{Zr}$ $\mathrm{C} 1$, (e) $\mathrm{Pt} / \mathrm{Zr}-\mathrm{C} 2$, (f) $\mathrm{Pt} / \mathrm{Zr}-\mathrm{C} 3$ and (g) $\mathrm{Pt} / \mathrm{Zr}-\mathrm{C} 4$ electrocatalysts. 
$0.2 \mathrm{~nm}$ which is calculated from peak at $39.9^{\circ}$ using the Scherer's formula.

Fig. 2(a-d) depicts FE-SEM and EDX images for various percentage of carbon nanoparticles held with $\mathrm{ZrO}_{2}$ nanospheres synthesized by the low temperature method followed by heat treatment at $500{ }^{\circ} \mathrm{C}$. Fig. 2 shows that both carbon and $\mathrm{ZrO}_{2}$ consist of nanospheres morphology. The EDX results indicate that the Pt composition comprises 39-41 wt\%. In addition to that, the percentage of carbon and Pt are calculated from EDX, CHNS, and ICP-OES as represented in Table 1. A higher magnified TEM image of $\mathrm{Pt}$ on carbon (commercial $\mathrm{Pt} / \mathrm{C}$ ) is shown in Fig. 3(a). The Pt metal nanoparticles are distributed uniformly on the carbon. Similarly the lower magnified image and particle size histogram also clearly show that, Pt nanoparticles are well distributed on carbon and the majority of particle size are found to be 1-3 $\mathrm{nm}$ as shown in Fig. 3(b and c). Fig. 3(d) shows a higher magnified TEM micrograph of Pt deposited on $\mathrm{Zr}-\mathrm{C}$ 3. The carbon nanoparticles are embraced in zirconia and the overall $\mathrm{Pt}$ metal nanoparticles are fairly distributed on $\mathrm{Zr}-\mathrm{C}$ 3. In addition, Fig. 3(e and f) reveal that, in the lower magnified region $\mathrm{Pt}$ nanoparticles are well distributed on $\mathrm{Zr}-\mathrm{C}$ and the maximum number of particle size are found to
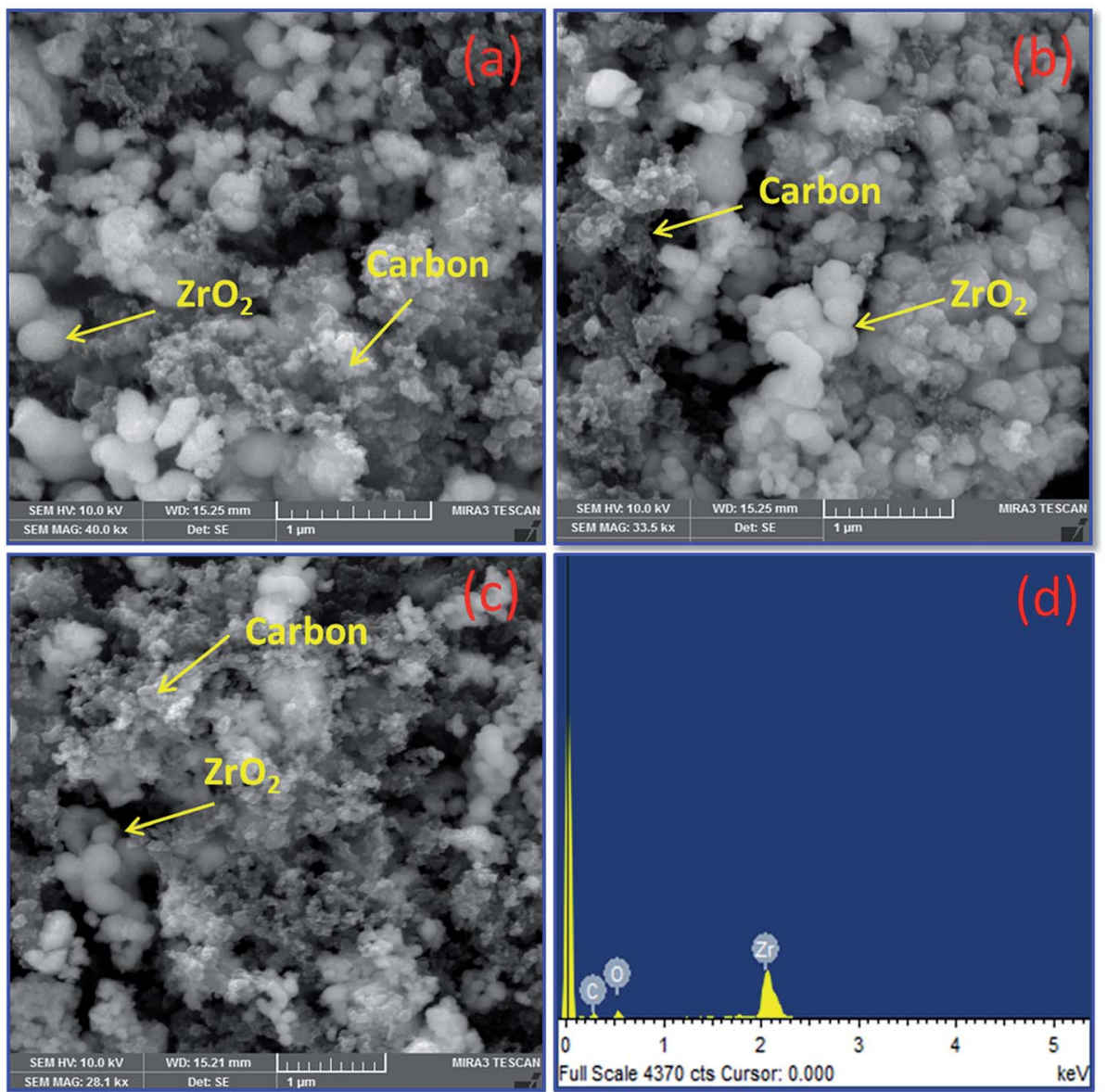

Fig. 2 FE-SEM image of (a) Zr-C 1, (b) Zr-C 3, (c) Zr-C 4 and (d) EDX for $\mathrm{Zr}-\mathrm{C} 3$.

Table 1 Percentage of carbon calculated using different methods

\begin{tabular}{|c|c|c|c|c|c|}
\hline Sample ID & \multicolumn{2}{|c|}{ Heat treated method $600{ }^{\circ} \mathrm{C} / 3 \mathrm{~h}$} & EDX C (wt\%) & CHNS analysis $\mathrm{C}( \pm 1 \%)$ & ICPOES $^{a}$ Pt wt $\%( \pm 2 \%)$ \\
\hline $\mathrm{ZrO}_{2}$ & $20 \mathrm{mg}$ & $19.8 \mathrm{mg}$ & 0 & 0 & 41 \\
\hline $\mathrm{Zr}-\mathrm{C} 1$ & $20 \mathrm{mg}$ & $18.0 \mathrm{mg}$ & $10-12$ & $9-10$ & - \\
\hline $\mathrm{Zr}-\mathrm{C} 2$ & $20 \mathrm{mg}$ & $16.1 \mathrm{mg}$ & $18-20$ & $14-15$ & 39 \\
\hline
\end{tabular}

${ }^{a}$ ICP-OES carried out for Pt deposited on carbon, $\mathrm{ZrO}_{2}, \mathrm{Zr}-\mathrm{C}$ materials. 

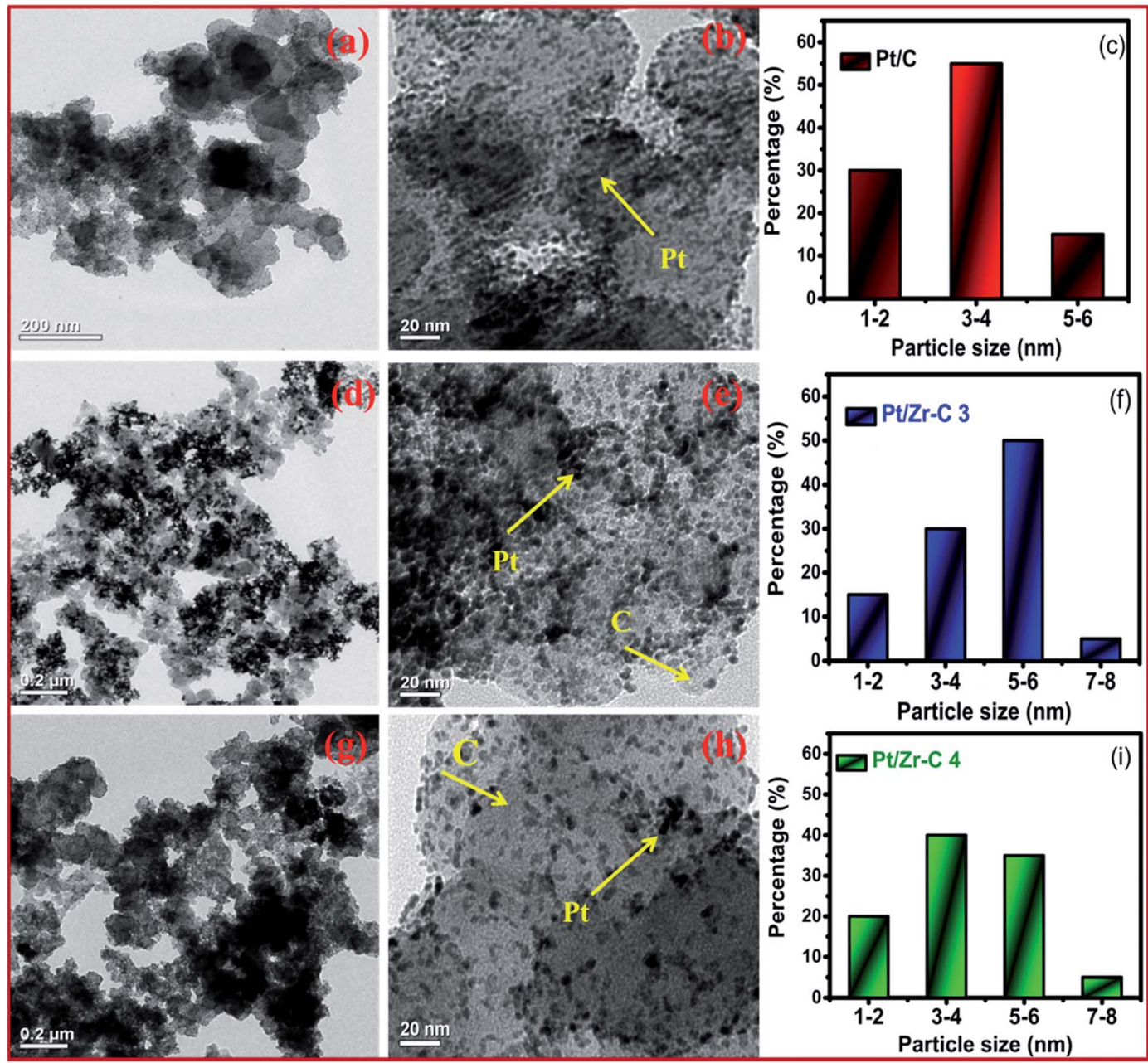

Fig. 3 TEM image of higher and lower magnified region and particles size histogram for $(\mathrm{a}-\mathrm{C}) \mathrm{Pt} / \mathrm{C},(\mathrm{d}-\mathrm{f}) \mathrm{Pt} / \mathrm{Zr}-\mathrm{C} 3 \mathrm{and}(\mathrm{g}-\mathrm{i}) \mathrm{Pt} / \mathrm{Zr}-\mathrm{C} 4$ electrocatalyst.

be 5-6 nm. Similarly, for $\mathrm{Zr}-\mathrm{C} 4$, there is a increased Pt distributution with decreased particle size as shown in Fig. 3(g-i). In addition, STEM image for Pt deposited on $\mathrm{Zr}-\mathrm{C} 3$ are represented in Fig. 4. The overall and individual elemental mapping also clearly show the distribution of carbon over the $\mathrm{ZrO}_{2}$ and also Pt metal nanoparticles are fairly distributed on $\mathrm{Zr}-\mathrm{C} 3$ framework.

To confirm the chemical oxidation state of $\mathrm{Pt} / \mathrm{Zr}-\mathrm{C} 3$ electrocatalyst, XPS measurement was carried out. XPS survey spectrum for $\mathrm{Pt} / \mathrm{Zr}-\mathrm{C} 3$ in Fig. 5(a) shows the predominant peaks of Pt, Zr, C, O and no other impurities are detected. Deconvoluted carbon 1s peak in Fig. 5(b) shows the four binding energy peaks such as 284.6 (C1), 285.3 (C2), 286.5 (C3) and 287.7 (C4) $\mathrm{eV}$ that are attributed to the graphitic $(\mathrm{C}-\mathrm{C})$ or $\mathrm{sp}^{2}$ hybridized carbon from carbon tapes, hydroxyl groups $(\mathrm{C}-\mathrm{OH})$, phenol/ether (C-O) or carbonated species and carbonyl/ quinone groups or $\mathrm{Zr}-\mathrm{O}-\mathrm{C}$ formation, respectively which is in good agreement with literature reports. ${ }^{16-19}$ Fig. 5 (c) shows the de-convoluted peak of $\mathrm{Zr} \mathrm{3d} \mathrm{5/2} \mathrm{and} \mathrm{3/2} \mathrm{at} 182.9$ and $185 \mathrm{eV}$ corresponding to $\mathrm{Zr}(+4)$ oxidation state of $\mathrm{ZrO}_{2}$ framework. ${ }^{20,21}$ Fig. 5(d) shows the Pt $4 \mathrm{f}$ core level peaks of $\mathrm{Pt} / \mathrm{Zr}-\mathrm{C} 3$, the solid peaks at 71.3 and $74.6 \mathrm{eV}$ are ascribed to $\mathrm{Pt} 4 \mathrm{f}_{7 / 2}$ and $4 \mathrm{f}_{5 / 2}$ which indicates the Pt in metallic state. Similarly, a minor doublet peak at 72.5 and $76.5 \mathrm{eV}$ and the smaller peak at 73.5 and $78.0 \mathrm{eV}$ are expected to be in Pt $(+2)$ and $(+4)$ oxidation states respectively.

ORR activity and catalyst stability were studied by using conventional three electrode configuration. Fig. 6(a) shows the CV curve for commercial and synthesized electrocatalyst in $\mathrm{N}_{2}$ saturated electrolyte solution at room temperature. Pt electrochemical surface area (ECSA) was calculated from CV in the region from 0.05 to $0.35 \mathrm{~V}$ for $\mathrm{Pt} / \mathrm{C}, \mathrm{Pt} / \mathrm{ZrO}_{2}, \mathrm{Pt} / \mathrm{Zr}-\mathrm{C} 1, \mathrm{Pt} / \mathrm{Zr}-\mathrm{C} 2$, $\mathrm{Pt} / \mathrm{Zr}-\mathrm{C} 3$ and Pt/Zr-C 4 to be 65, 18, 24, 32, 45, $59 \mathrm{~m}^{2} \mathrm{~g}^{-1}$ respectively. Fig. 6(b) shows the LSV curve for Pt deposited on C, $\mathrm{ZrO}_{2}$ and $\mathrm{Zr}-\mathrm{C}$ electrocatalyst in $\mathrm{O}_{2}$ saturated electrolyte solution at $1600 \mathrm{rpm}$. The onset potential of Pt deposited on $\mathrm{Zr}-\mathrm{C} 3$ and $\mathrm{Zr}-\mathrm{C} 4$ shows $0.9 \mathrm{~V}$ which is almost similar to $\mathrm{Pt} / \mathrm{C}$. Besides, the mass and specific activity of $\mathrm{Pt} / \mathrm{C}$ is observed to be $0.725 \mu \mathrm{A} \mu \mathrm{g}_{\mathrm{Pt}}{ }^{-1}$ and $0.0064 \mathrm{~mA} \mathrm{~cm}{ }^{-2} \mathrm{Pt}_{\mathrm{ECSA}}$ at $0.85 \mathrm{~V}$. Whereas, the optimum composition of $\mathrm{Zr}-\mathrm{C} 3$ supported $\mathrm{Pt}$ electrocatalyst shows the mass and specific activity of $0.875 \mu \mathrm{Ag}_{\mathrm{Pt}}{ }^{-1}$ and $0.01 \mathrm{~mA} \mathrm{~cm}{ }^{-2} \mathrm{Pt}_{\mathrm{ECSA}}$, which is higher than 

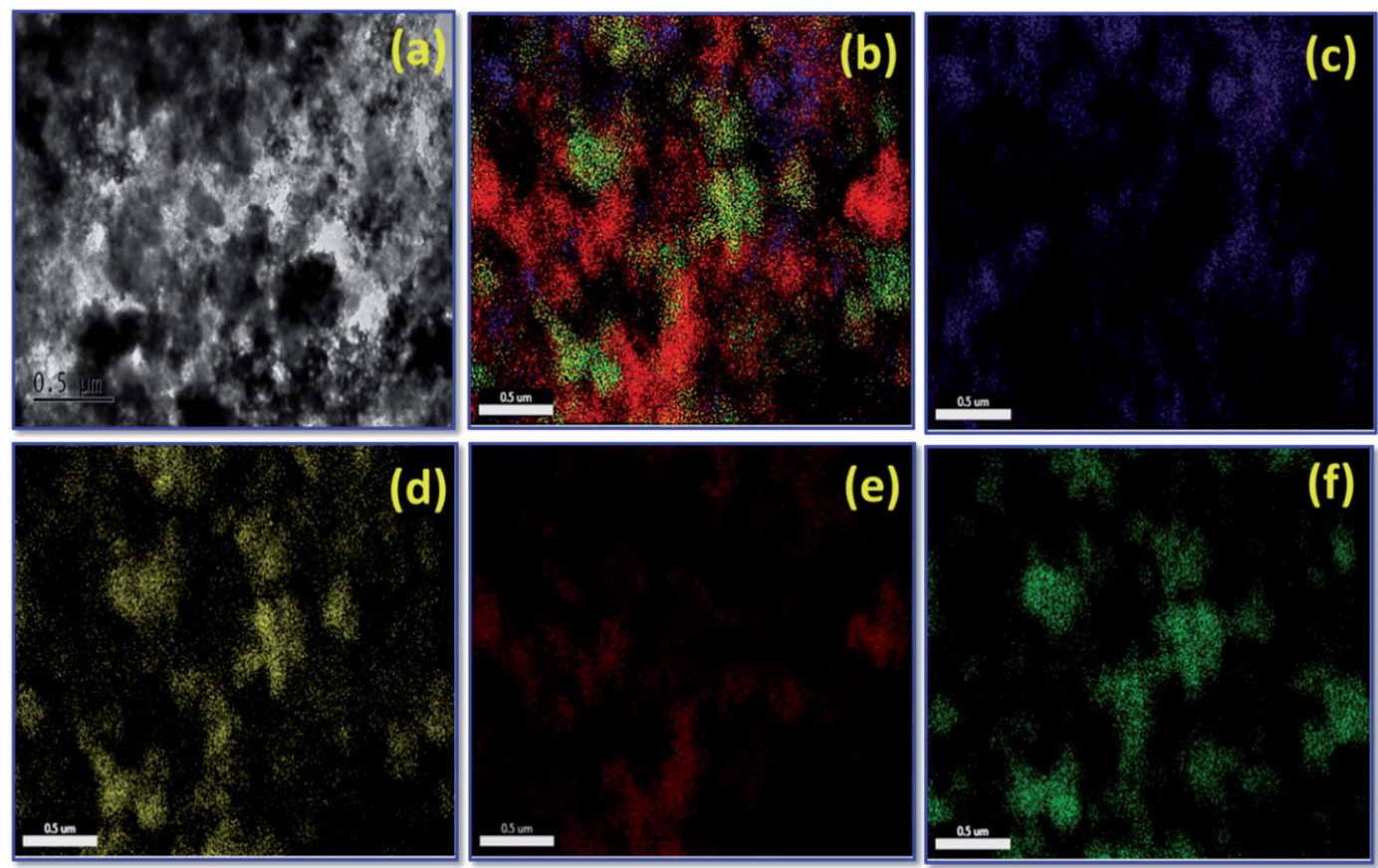

Fig. 4 HR-TEM image for (a) Pt/Zr-C 3, (b) S-TEM overall mapping for Pt/Zr-C 3, (c-f) individual elemental mapping, (c) carbon, (d) oxygen, (e) platinum and (f) zirconium.

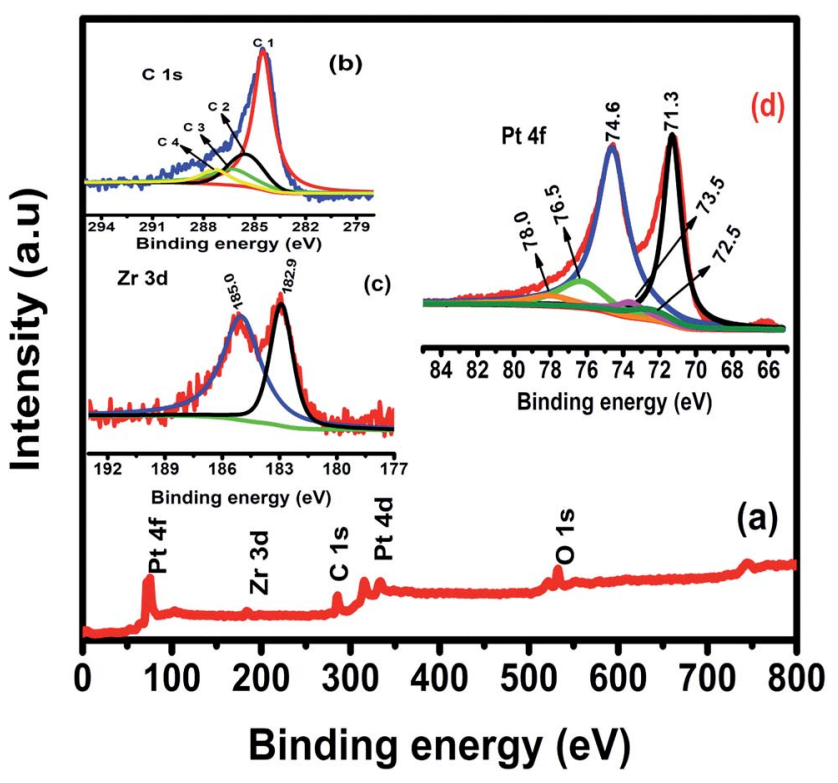

Fig. 5 (a) XPS survey spectra, (b) carbon 1s, (c) zirconium 3d and (d) platinum $4 \mathrm{f}$ orbitals.

that of other electrocatalyst. In addition, the electrocatalyst durability was conducted by potential cycling between 0.6 and $1.2 \mathrm{~V}$ in a $\mathrm{N}_{2}$-saturated $0.1 \mathrm{M} \mathrm{HClO}_{4}$ solution at a scan rate of $40 \mathrm{mV} \mathrm{s}^{-1}$. To calculate the ECSA at regular intervals, CV was recorded from 0 to $1 \mathrm{~V} v s$. RHE at scan rate of $20 \mathrm{mV} \mathrm{s}^{-1}$. Fig. 6(c) shows the CV at different intervals during the AST for $\mathrm{Pt} / \mathrm{Zr}-\mathrm{C} 3$. Fig. 6(c) shows that for Pt/Zr-C 3 after 2500 cycles, the ECSA dropped from 45 to $35 \mathrm{~m}^{2} \mathrm{~g}^{-1}$ and after 10000 potential cycles it is observed to be $22 \mathrm{~m}^{2} \mathrm{~g}^{-1}$.
The three electrode system experimental results confirm that, the Pt deposited on $\mathrm{Zr}-\mathrm{C} 3$ electrocatalyst has higher onset potential and specific activity than other synthesized electrocatalyst. In addition, a limiting current density of $5.8 \mathrm{~mA} \mathrm{~cm}^{-2}$ at $1600 \mathrm{rpm}$ is observed for $\mathrm{Pt} / \mathrm{C}$, which is in good agreement with theoretical value. ${ }^{22}$ However, slight variation in limiting current density for $\mathrm{Pt} / \mathrm{Zr}-\mathrm{C} 3$ is mainly due to the larger size of $\mathrm{Pt}$ particles and agglomeration as shown in Fig. 6(b). Our previous studies reported that, the initial ECSA of $\mathrm{Pt} / \mathrm{C}$ is observed as $65 \mathrm{~m}^{2} \mathrm{~g}^{-1}$ which is decreased to $20 \mathrm{~m}^{2} \mathrm{~g}^{-1}$ after 2500 AST cycles between 0.6 and $1.2 \mathrm{~V}$ and further rapidly reduced to $5 \mathrm{~m}^{2} \mathrm{~g}^{-1}$ after 10000 AST cycles. Similarly, the initial onset potential for ORR of Pt/C moved from $0.9 \mathrm{~V}$ to $0.7 \mathrm{~V}$ after 10000 cycles and the maximum limiting current density has come down to $2.8 \mathrm{~mA} \mathrm{~cm}^{-2}$ from $5.8 \mathrm{~mA} \mathrm{~cm}{ }^{-2} .^{23}$ The loss in ECSA and ORR activity for Pt/C during AST, may be due to carbon corrosion and Pt dissolution which is in good agreement with the various literature reports. ${ }^{\mathbf{4 , 5 2 , 2 5}}$ Whereas, for Pt on $\mathrm{Zr}$-C 3 electrocatalyst retains $48 \%$ of initial ECSA even after 10000 AST cycles as seen from Fig. 6(c). Similarly, LSV plots for $\mathrm{Pt} / \mathrm{Zr}-\mathrm{C} 3$ electrocatalysts before and after AST in $\mathrm{O}_{2}$-saturated $0.1 \mathrm{M} \mathrm{HClO}_{4}$ solution at a rotation rate of $1600 \mathrm{rpm}$ are shown in Fig. 6(d). The initial onset potential shifted from 0.9 to $0.83 \mathrm{~V}$ after 10000 cycles and limiting current densities change slightly in the ORR activity as shown in Fig. 6(d).

In order to determine the effect of the $\mathrm{ZrO}_{2}$ mass fraction towards fuel cell performance, fuel cells assembled with $\mathrm{Pt} / \mathrm{C}$, $\mathrm{Pt} / \mathrm{ZrO}_{2}, \mathrm{Pt} / \mathrm{Zr}-\mathrm{C} 1, \mathrm{Pt} / \mathrm{Zr}-\mathrm{C} 2, \mathrm{Pt} / \mathrm{Zr}-\mathrm{C} 3$ and Pt/Zr-C 4 cathode electrodes were examined at $100 \% \mathrm{RH}$ with cell operating temperature at $65{ }^{\circ} \mathrm{C}$. Fig. 7(a) shows the corresponding $I-V$ and power density curve. PEFC with $30 \mathrm{wt} \%$ of carbon held with 

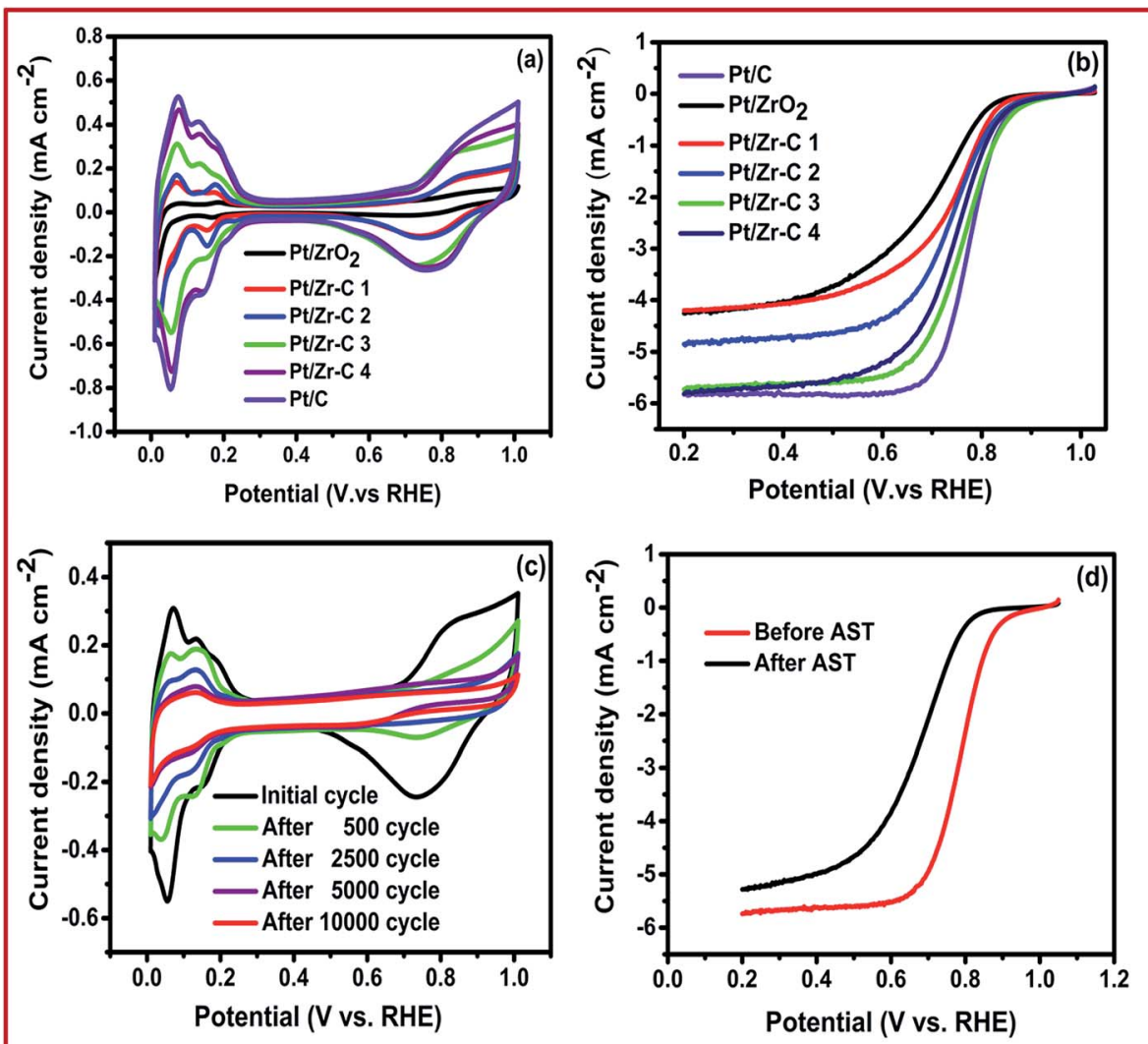

Fig. 6 (a) $\mathrm{CV}$ recorded in nitrogen saturated $0.1 \mathrm{M} \mathrm{HClO}_{4}$ solution, (b) $\mathrm{LSV}$ at $1600 \mathrm{rpm}$ recorded in oxygen saturated $0.1 \mathrm{M} \mathrm{HClO}_{4}$ solution, (c) accelerated stress test CV for $\mathrm{Pt} / \mathrm{Zr}-\mathrm{C} 3$ electrocatalyst and (d) LSV for before and after AST.

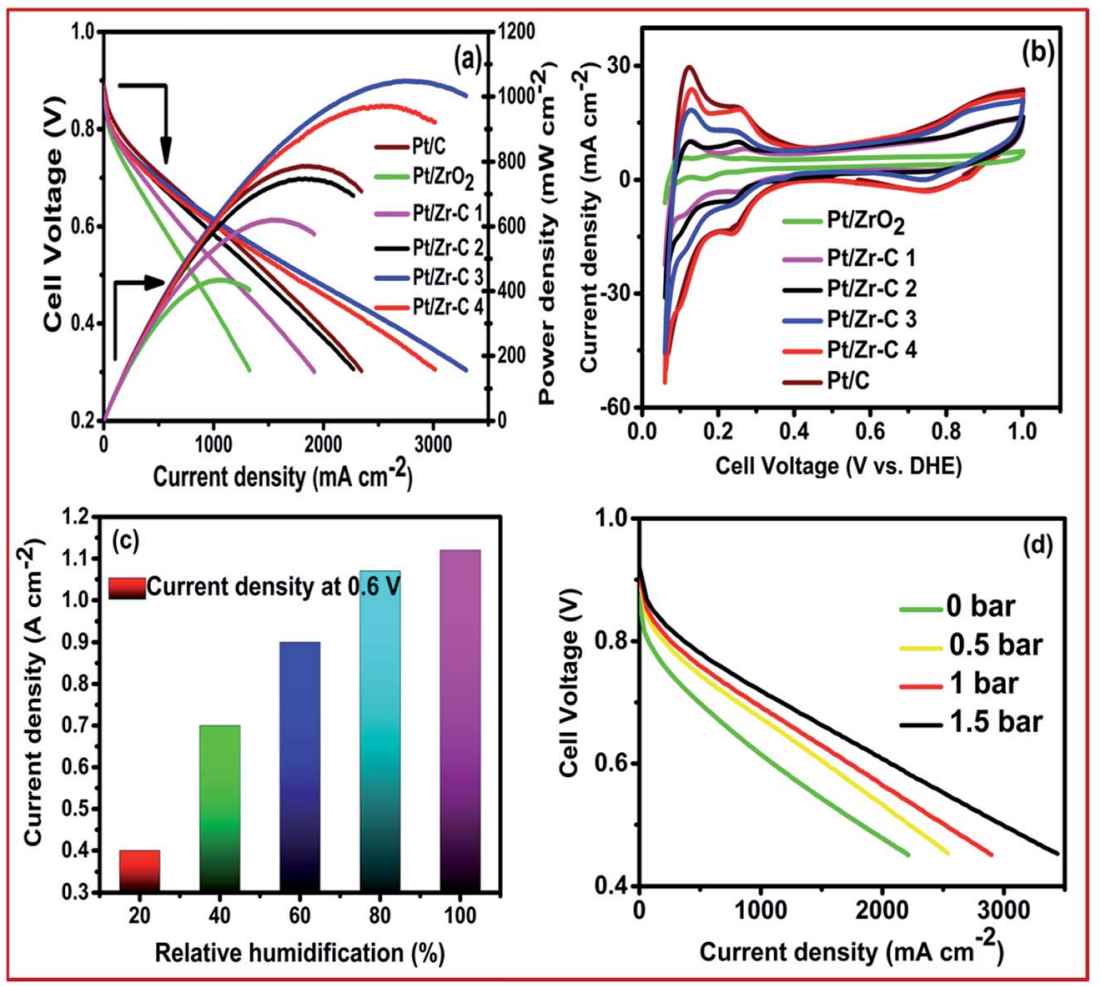

Fig. 7 (a) Steady state cell polarization (b) cyclic voltammetry, (c) effect of relative humidity and (d) effect of back pressure for cathode electrocatalysts. 
$\mathrm{ZrO}_{2}$ supported $\mathrm{Pt}(\mathrm{Pt} / \mathrm{Zr}-\mathrm{C} 3)$ delivers a higher current density of $1.15 \mathrm{~A} \mathrm{~cm}^{-2}$ at $0.6 \mathrm{~V}$ and a peak power density of $1.12 \mathrm{~W} \mathrm{~cm}^{-2}$ compared to $0.8 \mathrm{~W} \mathrm{~cm}^{-2}$ for Pt/C. Fig. 7(b) shows the cell mode cyclic voltammogram of $\mathrm{Pt} / \mathrm{C}$ and synthesized electrocatalysts. Fig. 7(c) shows that the effect of relative humidity for PEFCs with anode and cathode varied from 30 to $100 \%$ with the cell temperature maintained at $65{ }^{\circ} \mathrm{C}$. At $100 \%$ humidity at the cathode, a maximum current density of $1.15 \mathrm{~A} \mathrm{~cm}^{-2}$ at $0.6 \mathrm{~V}$ is observed. It is to be noted that cell performance at above $50 \%$ $\mathrm{RH}$ is not drastically decreased or changed. This results confirm that $\mathrm{ZrO}_{2}$-carbon composite framework has better water retention property in three phase boundary maintaining the fuel cell performance. Fig. 7(d) shows the effect of applying back pressure for $\mathrm{Pt} / \mathrm{Zr}-\mathrm{C} 3$ cathode electrocatalyst during the test.
The metal loading $\left(0.15 \mathrm{mg} \mathrm{cm}^{-2}\right)$ and relative humidity $(100 \%)$ is fixed for both anode and cathode, respectively. While applying back pressure from 0 to $1.5 \mathrm{bar}$, the peak power density of PEFC comprising Pt/Zr-C 3 cathode electrocatalyst increased from 1.15 to $2.2 \mathrm{~A} \mathrm{~cm}^{-2}$ at $0.6 \mathrm{~V}$.

The fuel cell electrocatalyst stability of synthesized electrocatalyst is studied by cycling from the potential range of 1 to $1.6 \mathrm{~V} v s$. DHE. As per the DOE protocol, there is a requirement of $50 \%$ of initial activity of the catalyst to be retained while cycling between 1 and $1.5 \mathrm{~V}$ up to 6000 cycles. In the present study, electrochemical stability and cell performance of Pt deposited on carbon (commercial), $\mathrm{Zr}-\mathrm{C} 1, \mathrm{Zr}-\mathrm{C} 3$ and $\mathrm{Zr}-\mathrm{C} 4$ were studied by potential cycling between 1 and $1.6 \mathrm{~V} v s$. DHE with a scan rate of $500 \mathrm{mV} \mathrm{s}^{-1}$. During the accelerated stress test (AST) cycles,
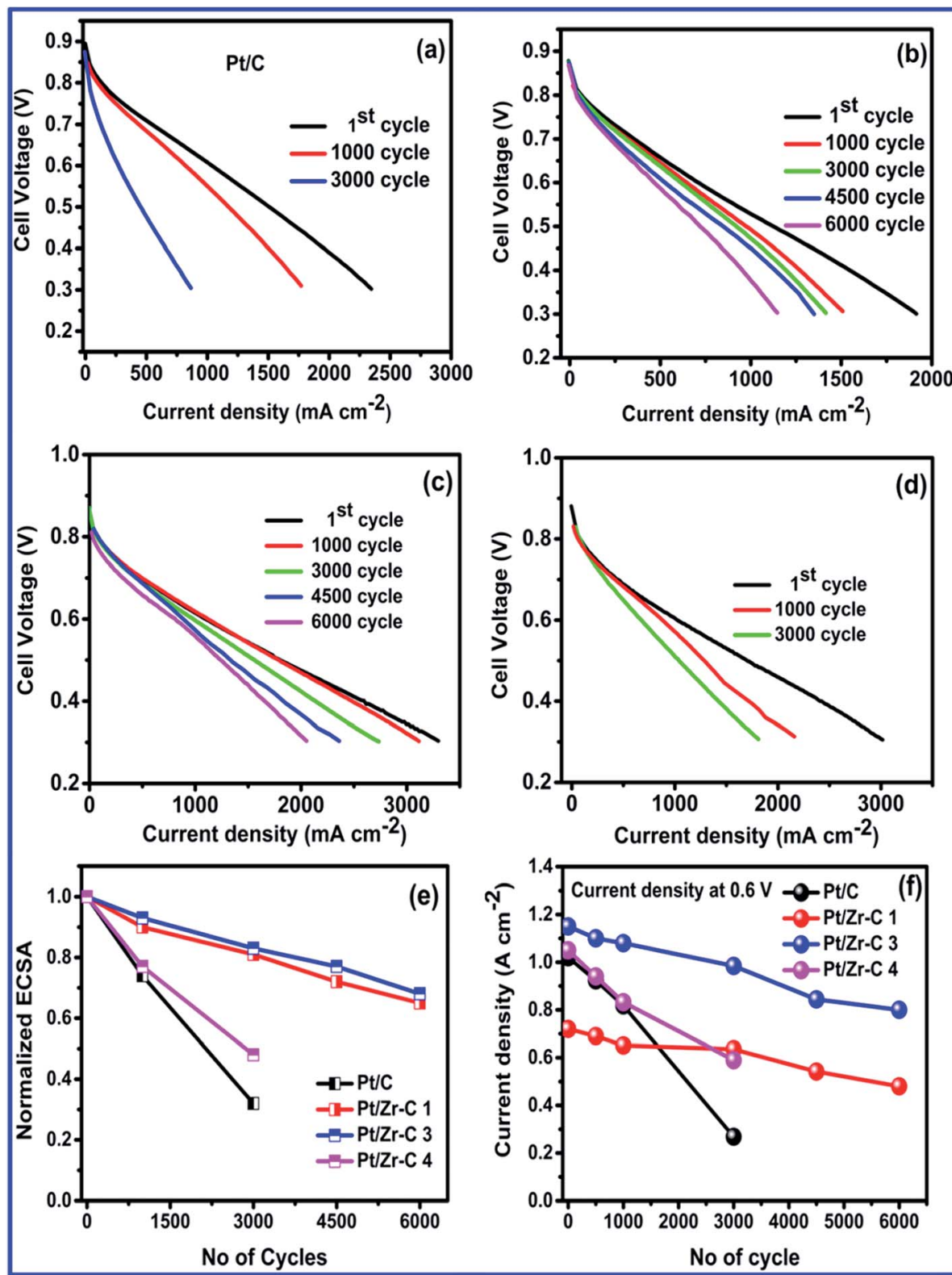

Fig. 8 AST cycling between 1 and $1.6 \mathrm{~V}$, (a-d) before and after AST for Pt/C, Pt/Zr-C 1, Pt/Zr-C 3 and Pt/Zr-C 4, (e) normalized ECSA and (f) current density vs. number of cycles. 
hydrogen gas $\left(200 \mathrm{ml} \mathrm{min}{ }^{-1}\right)$ was passed into the anode and

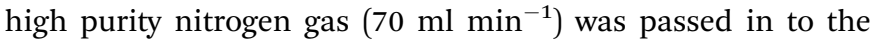
cathode while $100 \%$ RH was maintained with a cell temperature of $75^{\circ} \mathrm{C}$. The gas flow rates were controlled by digital mass flow controllers. The steady state polarizations and cyclic voltammetry (CV, from 0.05 to 1 vs. DHE) were recorded at regular intervals. Fig. 8(a) shows the $I-V$ for commercial Pt deposited on carbon. Before AST, a current density of $1.025 \mathrm{~A} \mathrm{~cm}^{-2}$ at $0.6 \mathrm{~V}$ is observed for Pt/C. After 1000 and 3000 AST cycles, the initial cell performance dropped drastically and is observed to be 0.57 and $0.29 \mathrm{~A} \mathrm{~cm}^{-2}$ respectively. Fig. 8(b) shows $\mathrm{Pt} / \mathrm{Zr}-\mathrm{C} 1$ with minimal amount of carbon, the current density slightly reduced from 0.70 to $0.5 \mathrm{~A} \mathrm{~cm}^{-2}$ even after 6000 potential cycles. Fig. 8(c) for $\mathrm{Pt} / \mathrm{Zr}-\mathrm{C} 3$ with optimum percentage shows a current density of $1.15 \mathrm{~A} \mathrm{~cm}^{-2}$ at $0.6 \mathrm{~V}$ before AST, however after 6000 AST cycles, current density is retained to $0.82 \mathrm{~A} \mathrm{~cm}^{-2}$. Similarly, Fig. 8(d) for $\mathrm{Pt} / \mathrm{Zr}-\mathrm{C} 4$ with higher carbon content, the current density was observed during the AST from 1.07 to $0.60 \mathrm{~A} \mathrm{~cm}^{-2}$ after 3000 potential cycles.

The normalized ECSA and current density for Pt/C and synthesized electrocatalysts in relation to AST cycles is given in Fig. 8(e and f). ECSA decreased for both $\mathrm{Pt} / \mathrm{C}$ and carbon rich $\mathrm{Zr}-$ C 4 supported Pt after 3000 cycles. However, the optimum level of carbon inter-connected with $\mathrm{ZrO}_{2}(\mathrm{Zr}-\mathrm{C} 1$ and $\mathrm{Zr}-\mathrm{C} 3)$ retains $70 \%$ of initial ECSA even after 6000 cycles. Similarly, $I-V$ curves also clearly show that $\mathrm{Pt} / \mathrm{Zr}-\mathrm{C} 1$ and $\mathrm{Pt} / \mathrm{Zr}-\mathrm{C} 3$ retain $70 \%$ of the initial fuel cell performance even after 6000 cycles, whereas the performance of $\mathrm{Pt} / \mathrm{C}$ and $\mathrm{Pt} / \mathrm{Zr}-\mathrm{C} 4$ is reduced by up to $50 \%$ from the initial value after 3000 cycles.

During AST, 1000-1500 ppm of $\mathrm{CO}_{2}$ emission was observed for $\mathrm{Pt} / \mathrm{C}$ at the cathode outlet, which clearly indicated that carbon corrosion happens at a potential higher than 1 V. For Pt/ $\mathrm{Zr}-\mathrm{C} 3$, only 150-300 ppm of $\mathrm{CO}_{2}$ emission was observed. This may be due to corrosion of carbon which is not held in $\mathrm{ZrO}_{2}$. Similarly, the $\mathrm{CO}_{2}$ emission for carbon rich Zr-C 4 was 1000$1200 \mathrm{ppm}$ and for the composite with lower amount of carbon (Zr-C 1), the emission was 100-200 ppm. In addition, inductively coupled plasma optical emission spectroscopy studies (ICP-OES) were conducted on the by-product (water) derived from the cathode outlet of the sample for which AST was carried out. ICP-OES results show that Pt dissolution for $\mathrm{Pt} / \mathrm{C}, \mathrm{Pt} / \mathrm{Zr}-\mathrm{C} 1$, $\mathrm{Pt} / \mathrm{Zr}-\mathrm{C} 3$ and Pt/Zr-C 4 are 0.83, 0.42, 0.5 and $0.66 \mathrm{mg} \mathrm{L}^{-1}$, respectively.

The fuel cell experimental results also clearly show that the carbon held with $\mathrm{ZrO}_{2}$ materials enhances the fuel cell performance and retained the Pt ECSA and long-term durability in PEFCs. Zirconia could prevent the Pt nanoparticles agglomeration, migration and also reduce the carbon corrosion. According to ICP-OES result, Pt diffusion of dissolved Pt species on carbon increased, whereas Pt dissolution decreased while increasing the mass fraction of $\mathrm{ZrO}_{2}$ in relation to carbon. Scheme 1 illustrate the $\mathrm{Pt} / \mathrm{C}$ and $\mathrm{Pt} / \mathrm{Zr}-\mathrm{C} 3$ electrocatalysts degradation process during AST. For Pt deposited on carbon fuel cell performance was rapidly decreased during AST due to (1) increased carbon corrosion confirmed from $\mathrm{CO}_{2}$ emission, (2) agglomeration of Pt particle, (3) dissolution of Pt particles confirmed from ICP-OES which is in good agreement with literatures. ${ }^{3,4,21,24}$ Whereas, for Pt on optimum level of carbon composite with $\mathrm{ZrO}_{2}(\mathrm{Pt} / \mathrm{Zr}-\mathrm{C} 3)$ during the AST shows that $70 \%$ of initial performance is retained due to (1) reduced carbon corrosion (confirmed from $\mathrm{CO}_{2}$ emission) as compared to $\mathrm{Pt} / \mathrm{C}$, (2) stabilized Pt nanoparticles, (3) re-deposition of Pt nanoparticles on the $\mathrm{ZrO}_{2}$ : $\mathrm{C}$ composite during the AST (minimal Pt dissolution loss is observed as compared to $\mathrm{Pt} / \mathrm{C}$ confirmed from ICP-OES). It is evident that $\mathrm{Zr}-\mathrm{C} 3$ supported $\mathrm{Pt}$ has higher durability and is found to be more stable than $\mathrm{Pt} / \mathrm{C}$.

We report the stability and long-term durability of Pt deposited on $\mathrm{Zr}-\mathrm{C}$ electrocatalysts and the optimum level of carbon held with $\mathrm{ZrO}_{2}$ nanospheres ( $\mathrm{Pt} / \mathrm{Zr}-\mathrm{C} 3$ ) retains more than $70 \%$ of initial fuel cell performance and ECSA even after 6000 cycles between 1 and $1.6 \mathrm{~V}$. As envisaged, optimum level of Vulcan XC 72 carbon composite with $\mathrm{ZrO}_{2}$, shows increasing fuel cell performance than Pt/C by improved electron transfer. As inferred, optimum level of carbon makes ideal electrical pathway with reduced $\mathrm{ZrO}_{2}$ resistance and further enhanced the triple phase boundary with more engaging Pt nanoparticles. It is to be noted that optimizing the carbon content in $\mathrm{ZrO}_{2}$ is critical as excess carbon may partially cover the active sites and prevent the oxygen transfer. ${ }^{26-31}$ The experimental results also clearly shows that Pt deposited on metal oxide-carbon composite $\left(\mathrm{ZrO}_{2}-\mathrm{C}\right)$ is

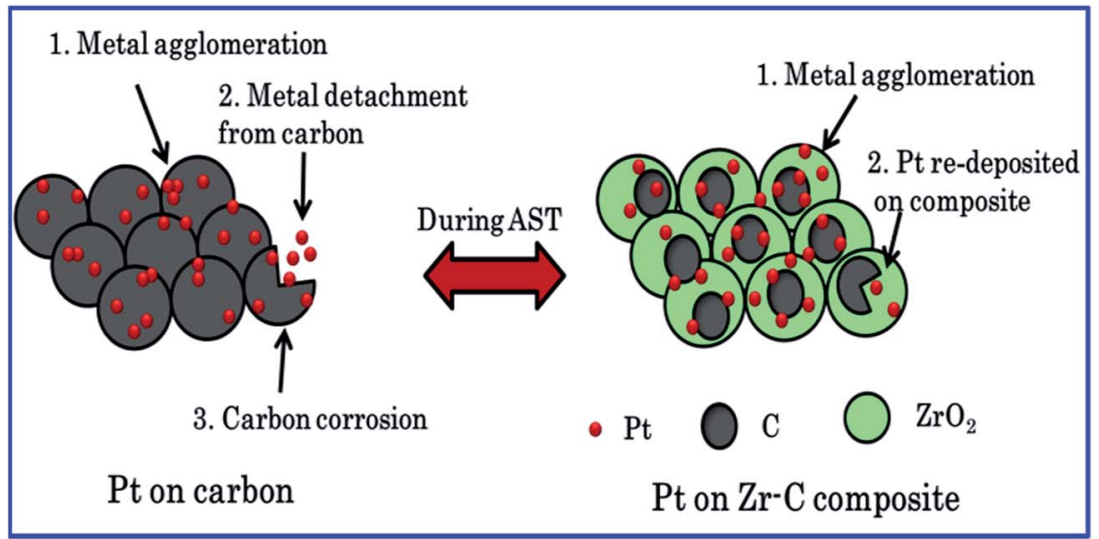

Scheme 1 Corrosion during the AST for Pt on carbon and Pt on $\mathrm{Zr}-\mathrm{C} 3$ composite. 
more suitable to improve strong interaction between $\mathrm{Pt}-\mathrm{ZrO}_{2}-\mathrm{C}$ and effectively prevent the Pt agglomeration, dissolution and carbon corrosion, retaining long term stability of PEFCs. Thus, optimum levels of carbon held with $\mathrm{ZrO}_{2}$ supported Pt proves to be stable under detrimental conditions such as higher potentials ( 1 to $1.6 \mathrm{~V}$ ) and low RH. Future studies are in the direction towards $100 \mathrm{~cm}^{2}$ active area membrane electrode assemblies with 3 cell stack durability from indigenous cell fixture design using Zr-C 3 supported Pt electrocatalyst.

\section{Conclusions}

Pure tetragonal phase $\mathrm{ZrO}_{2}$ nanospheres held carbon was synthesized by low temperature method. $\mathrm{ZrO}_{2}$ held carbon supported Pt as cathode electrocatalyst has enhanced the fuel cell performance. Suitable optimization of carbon held with $\mathrm{ZrO}_{2}$ supported Pt improves the long-term durability even after 6000 potential cycles between 1 and $1.6 \mathrm{~V}$. The AST results have shown that $\mathrm{Pt}$ on $\mathrm{Zr}-\mathrm{C}$ composite has more stability than $\mathrm{Pt}$ deposited on carbon. Physical and electrochemical characterization results, confirmed that an optimum level of carbon held $\mathrm{ZrO}_{2}$ supported $\mathrm{Pt}$ is a more promising alternative cathode electrocatalyst for PEFCs.

\section{Conflicts of interest}

There are no conflicts to declare.

\section{Acknowledgements}

SDB is thankful for a CSIR-YSA research grant (DU-MLP-0090) and PD thanks CSIR for the funding through Research Associateship.

\section{References}

1 S. P. S. Badwal, S. S. Giddey, C. Munnings, A. I. Bhatt and A. F. Hollenkamp, Front. Chem., 2014, 2, 1-28.

2 U. S. Department of Energy, Energy Efficiency and Fuel Cell Technologies, in Comparison of Fuel Cell Technologies, 2011 March.

3 J. Larminie and A. Dicks, Fuel cell systems explained, Wiley, England, 2003.

4 E. Antolini, Appl. Catal., B, 2009, 88, 1-24.

5 E. Antolini, J. Mater. Sci., 2003, 38, 2995-3005.

6 Z. Zhang, J. Liu, J. Gu, L. Su and L. Cheng, Energy Environ. Sci., 2014, 7, 2535-2558.

7 P. Dhanasekaran, S. V. Selvaganesh and S. D. Bhat, J. Power Sources, 2016, 304, 360-372.

8 H. Lu, N. Cheng, T. Peng, M. Pan and S. Mu, J. Mater. Chem., 2012, 22, 1135-1141.
9 L. Li and W. Wang, Solid State Commun., 2003, 127, 639-643.

10 J. Lu, J. B. Zang, S. X. Shan, H. Huang and H. Wang, Nano Lett., 2008, 8, 4070-4074.

11 G. Liu, H. Zhang, H. Zhong, J. Hu, D. Xu and Z. Shao, Electrochim. Acta, 2006, 51, 5710-5714.

12 G. Liu, H. Zhang and Y. Ma, Mater. Sci. Forum, 2007, 561, 1589-1592.

13 Y. Bai, J. Wu, J. Xi, J. Wang, W. Zhu, L. Chen and X. Qiu, Electrochem. Commun., 2005, 7, 1087-1090.

14 N. Cheng, M. N. Banis, J. Liu, A. Riese, X. Li, R. Li, S. Ye, S. Knights and X. Sun, Adv. Mater., 2014, 27, 277-281.

15 M. J. Lazaro, L. Calvillo, V. Celorrio, J. I. Pardo, S. Perathoner and R. Moliner, Study and application of carbon black vulcan $X C-72 R$ in polymeric electrolyte fuel cells, Nova Science Publishers, Inc, 2011, ch 2.

16 S. M. Senthil Kumar, J. S. Herrero, S. Irusta and K. Scott, J. Electroanal. Chem., 2010, 647, 211-221.

17 Q. Xiao and L. Ouyang, Chem. Eng. J., 2009, 148, 248-253.

18 P. Dhanasekaran, S. V. Selvagenesh and S. D. Bhat, New J. Chem., 2017, 41, 13012-13026.

19 M. Balaceanu, M. Braic, V. Braic, A. Vladescu and C. C. Negrila, J. Optoelectron. Adv. Mater., 2005, 7, 2557-2560.

20 S. N. Basahel, T. T. Ali, M. Mokhtar and K. Narasimharao, Nanoscale Res. Lett., 2015, 10(73), 1-13.

21 C. D. Wagner, W. M. Riggs, L. E. Davis, L. F. Moulder and D. Briggs, Handbook of X-ray photoelectron spectroscopy, Perkin Elmer Corporation, USA, 1979.

22 K. J. Mayrhofer, D. Strmenik, B. B. Blizanac, V. Stamenkovic, M. Arenzand and N. M. Markovic, Electrochim. Acta, 2008, 53, 3181-3188.

23 P. Dhanasekaran, S. V. Selvaganesh and S. D. Bhat, New J. Chem., 2017, 41, 2987-2996.

24 S. K. Zevevic, J. S. Wainright, M. H. Litt, S. L. Gojkovic and R. F. Savinell, J. Electrochem. Soc., 1997, 144, 2973-2982.

25 J. Speder, A. Zana, I. Spanos, J. J. Kirkensgaard, K. Mortensen, M. Hanzlik and M. Arenz, J. Power Sources, 2017, 261, 14-22.

26 H. N. Yang, W. H. Lee, B. S. Choi, Y. D. Ko, S. C. Yi and W. J. Kim, Energy, 2017, 120, 12-19.

27 S. Chung, M. Choun, B. Jeong, J. Lee and J. Lee, J. Energy Chem., 2016, 25, 258-264.

28 Y. Ji, Y. Cho, Y. Jeon, C. Lee, D. Park and Y. Shul, Appl. Catal., $B, 2017,204,421-429$.

29 R. Wang, K. Wang, H. Wang, Q. Wang, J. Key, V. Linkov and S. Ji, Int. J. Hydrogen Energy, 2013, 38, 5783-5788.

30 T. Mittermeier, P. Madkikar, X. Wang, H. A. Gasteiger and M. Piana, J. Electrochem. Soc., 2016, 163, F1543-F1552.

31 N. Cheng, J. Liu, M. N. Banis, D. Geng, R. Li, S. Ye, S. Knights and X. Sun, Int. J. Hydrogen Energy, 2014, 39, 15967-15974. 